\title{
The Effect of Technology Information, Organizational Commitment, Internal Control and Good Corporate Governance Principles on Organizational Performance
}

\author{
Wildoms Sahusilawane \\ Faculty of Economics, Universitas Terbuka Ambon Regional Office, Indonesia
}

\section{A R T I C L E I N F O \\ Article history: \\ Received 12 February 2020 \\ Received in revised form \\ 29 March 2020 \\ Accepted 18 April 2020 \\ Available online 30 May \\ 2020}

Keywords:

Information Technology,

Commitment, Internal

Control, Principles of

GCG, Organizational

Performance

\begin{abstract}
A B S T R A C. T
This research aimed to critically evaluate information technology, organizational commitment, internal control, and the implementation of the principles of Good Corporate Governance (GCG) and describe how the key elements of these constructs contribute to the performance of PT. Bank Maluku. To this end, a sample of 40 employees at PT Bank Maluku identified and examined using non probability purposive sampling. Primary data results from questionnaires complemented by interviews for data collection. The data analysed using correlation analysis and multiple regression that includes descriptive statistics and reliability and validity test of the research instrument. The research study proceeds to classical assumption test including multicollinearity test, hypothesis testing within the model and discussion on result. The results of the analysis based on $t$ test greatly vary. Information technology is found negative and non-significant in organizational performance. Both organizational commitment and internal control, to the contrary, pose positive yet non-significant effect on organizational performance, while the implementation of the principles of good corporate governance poses positive relationship and are statistically significant in organizational performance.
\end{abstract}

\footnotetext{
* Corresponding author.

E-mail addresses: Wildoms27@gmail.com (Wildoms Sahusilawane)
} 


\section{Introduction}

Keberadaan A relation between service companies and the current economic development in Indonesia is apparent. It is transforming service companies such as financial services in very significant ways that create an imperative for banking institutions to reconsider their organizational systems, particularly management practices, in relation to their direct contribution to society. Management practices determine whether an organization is performing particular functions and activities efficiently. Effective management performance is at its best when it defines the organization's overall objectives and ways to support these objectives.

It is essential to analyze the process of managerial performance and evaluate its outcome to measure whether it is in line with standards that meet business goals and live up to shareholders' expectations. Inventing and reinventing managerial performance have intrigued researchers for years. Hall (2004) mentions managerial performance as one tool by which managers and employees work together to plan, monitor and review objective-setting and assess its progress. Rustiana (2004) asserts that managers are required to conceive bold new visions and ground these visions in practical terms with the intent of translating them into concrete steps to actualize them. When managers successfully do this, employee engagement and organization productivity increase, and challenges in future prospects can be predicted and addressed.

The implementation of Good Corporate Governance (GCG) is the staple of underpinning the integrity and efficiency of an organization, which in turn improves performance and builds trust among its shareholders, customers and public, in general. GCG provides broad paramaters of efficiency, accountability and sound decision-making and encompasses interactive relationships and participations among myriad constituents in identifying direction and performance of an organization. Simarmata (2007) contends that GCG concentrates on relationships between management, directors, commissioners, shareholders and stakeholders regarding organizational objectives, strategies and achievements. It is a system and a set of rules that ensure value creation and sustainable success.

In terms of regulations, banking industries are subject to a more rigorous supervisory scheme than others. For example, a bank shall comply with the minimum Current Adequacy Ratio (CAR) to measure its financial soundness. Bank Indonesia (BI) uses financial statement to provide a reasonable basis for determining whether the condition of the banking system remains stable. Managers, as a result, have incentives to make earnings management to ascertain the announced number is at least equal to the earning expected by BI (Rahmawati and Baridwan, 2006).

Bank Indonesia Regulation No. 8/4/PBI/2006 outlines the framework of Good Corporate Governance as a reference for a sound corporate governance through the application of transparency, accountability, responsibility, interdependency and fairness principles. As the regulator and supervisor in banking practices in Indonesia, Bank Indonesia, along with related entities, should ensure compliance with applicable laws, standards, rules, rights and duties of all interested parties. The fundamental success of a bank to create profitable growth heavily depends on the managerial achievement (Ristifani, 2009).

Nowadays, the demand for good corporate governance establishment which can secure the benefits associated with business planning, management controlling and decision making is seeping into every corner of public business sector. Internal control plays an important role in management functions that involve setting objectives, identifying a course of measures to accomplish these objectives, controlling them to ensure they are moving along as planned and good decision making (Mardiasmo, 2004).

Internal control refers to a process operated by board of commissioners, management and other business personnels to provide a sufficient assurance regarding the achievement of organizational strategic objectives (IAI, 2001). Large companies including developing companies engage in a large-scale internal control. Without such, most business organizations, particularly those with numerous locations, operations and employees in a large number of divisions and subdivisions, will operate inefficiently, in an unreliable manner and out of compliance with applicable laws - thus allowing high rates of errors and the occurences of unforeseeable circumstances. Ranti Oktari (2011) and Gustika Yolanda Putri (2012) point out that internal control is an integral part of organizational performance, assuring achievement of organizational objectives in terms of operational efficiency. Pratolo (2006), in a similar sense, observes the performance of a regional hospital and finds that internal control provides a strong basis upon which the underlying principles of good corporate governance and performance are set. However, the positive partial effect of the organizational commitment, internal control and the principles of good corporate governance on the hospital performance is not significant.

In addition to implementing good corporate governance, organizations that use widespread optimized information technology can improve business performance. Information technology in the context of business refers to the application of computers as the main tool to process and store data from 
which useful information is extracted. Coping with recent advances of information technology and great flood of information has led to the need for a more sophisticated way of handling information better and faster. Banking institutions, consequently, are moving rapidly to embrace digital platforms, such as websites, that allow customers to rapidly and easily access a wide range of information about their services.

Tugiman (2000) argues that good corporate governance starts with a commitment to setting a clear strategy for the organization. A highly committed organization will maintain efficiency and effectiveness in the dynamic nature of business environment which are central terms in assessing and measuring its overall performance. This commitment is created by the entire individual components at all levels of the organization to make a strong impact on the organizational values. Organizational commitment brings added values to the organization when these individual components identify with the organizational goals, have a profound desire to belong to the organization and are willing to go over and beyond their required job duties to invigorate continuing collective business endeavors.

PT. Bank Maluku Tbk is a Regional-Owned Enterprise (BUMD) whose bulk of share is owned by the regional government. It is established in a comprehensive governance operating a framework in accordance with the laws and regulations, i.e., Limited Liability Company (PT) regulations, Bank Indonesia regulations and Financial Service Authority (OJK). By ensuring that it is adherent to these regulatory compliance, PT. Bank Maluku is expected to represent a consistent development in the long-standing efforts to promote sound corporate governance practices for its banking operations.

The present study sets out to evaluate the extent of the application of information technology, organizational commitment, internal control and the implementation of the principles of good corporate governance at PT. Bank Maluku and determine whether they fit into its progress of performance.

Good corporate governance encourages business management to pursue objectives that are in the interests of the shareholders and the users of the resources, thereby enabling organizations to promote efficient use of their resources based on practices by which they can ensure fairness, efficiency, transparency and accountability (Wardani, 2010). Efendi (2009) defines good corporate governance with respect to organizations' internal control system that pursues the primary goal of managing risks with the intent of meeting its business objectives through securing corporate assets and increasing shareholders' values in a long term. Prakarsa (2009) highlights the role of good corporate governance in establishing administrative mechanisms that govern a set of relationships between management, board of commissioners, board of directors, shareholders and stakeholders.

The basic principles of good corporate governance emerge from four pillars, as Kaihatu (2006) breaks down below:

1) Transparency, which refers to the extent to which an organization has ready access to any required financial information about its business. In this sense, a company should share, disclose and publish information to the interested parties to identify what has happened to infer what can happen in the future regarding its business operations. An organization's annual report should be understandable and provide information necessary for the shareholders to assess its position and performance, particularly when it goes public. In addition to information disclosure, transparency is a management method where all decision making is carried out publicly and remain publicly archived.

2) Fairness, which takes into account equal treatment of all stakeholders and shareholders, including minority and foreign shareholders, and protection of their rights in compliance with applicable agreements and laws without benefiting any particular group of interests better than others.

3) Accountability, which supports the obligation of an organization to account for the clarity of the function, implementation and liability of its organs to carry out effective management. Accountability improves directors' incentives to monitor management and reduces agency problems.

4) Responsibility, which emphasizes the importance of pursuing business operations that abide by the applicable laws, regulations and standards for sound corporates. This compliance helps ensure the organization is aware of and takes steps to adhere to these laws and the goal the company aspires to achieve is in place and functions effectively.

Information technology, according to Nugroho (2001), emphasizes the application of a computer system and is closely associated with the arrangement of information sources. Aren (2003) contends that information technology is employed to collect, process and present information. Kadir (2003) classifies the roles of information technology into the following; 1 ) it replaces human labors when it comes to automating existing tasks, which can be time- and cost-effective; 2) it reinforces and strengthens human roles in a way that allows them to appropriately present information to a task; 3) it is a tool of restructuring human roles, allowing changes in a set of tasks.

Internal control, as put by The Indonesian Institute of Accountants in Standar Profesional Akuntan Publik (2001), represents a method used by board of commissioners, management and other personnels 
to provide a reasonable assurance on achievement of the following organization's objectives: 1) Reliable financial reporting, 2) Operational effectiveness and efficiency, and 3)Compliance with existing laws and regulations

In Government Regulation No. 60/2008, internal control system is defined as an integral part of sustainable tasks and activities by all employees which aims to provide a reasonable assurance about the achievement of established objectives regarding effective and efficient operating performance, the reliability of financial reporting, security of assets and compliance with applicable laws.

Organizational commitment, as defined by Luthans (2006), refers to employees' profound willingness to maintain membership due to interest and association with the organization's goals and values, the strong degree to which they engage in their work and their belief in, acceptance of and attachment to the organizational goals. It is beyond passive loyalty and, rather, deals with active relationships and personal desires to fully embrace the organizational cultures and goals.

Sopiah (2008) sets out three underlying factors that lead to organizational commitment, viz., a strong belief in and acceptance of the organizational values and goals, willingness to exert considerable effort on behalf of the organization and a strong desire to maintain membership of the organization.

Organizational performance, as defined by Chaizi Nasucha in Irham Fahmi (2013), is an organization's overall effectiveness and achievement in relation with its set goals. It includes systematic ongoing efforts toward goals the organization aspires to achieve. It represents measurable outcomes of organizational activities and describes an empirical condition of an organization based on agreed dimensions. Performance measurement consists of an assessment tool to measure organizational effectiveness.

A wide strand of previous findings on information technology, organizational commitment, internal control and the principles of good corporate governance attributed to organizational performance enables us to empirically re-examine the existing studies, allowing an expansion of past work in the field. Pratolo Suryo (2008) sheds light on the effect of management audit, managers' organizational commitment, internal control over the principles of good corporate governance and the performance of GovernmentOwned Enterprises of Indonesia. His study establishes no significant effect of management audit and manajerial commitment upon implementing the principles of good corporate governance. Internal control and the principles of good corporate governance, to the contrary, affect the performance of the Government-Owned Enterprises.

In a similar sense, Irfan Dwi Priambodo (2015) in his study "The Effect of the Principles of Good Corporate Governance (GCG), Internal Control and Information Technology on Manajerial Performance (A Study on RSUD Dr. Soeselo in Tegal) shows significant effects of the principles of good corporate governance, internal control and information technology on manajerial performance.

\section{Methods}

The study is conducted on 50 employees of PT. Bank Maluku.Tbk in Maluku Province, including the branch heads in West Seram Regency, Ambon City and Middle Maluku Regency. Purposive sampling is selected based on specific criteria chosen by the judgment of the researcher associated with addressing the purpose of the study.

The study uses quantitative data, focusing on gathering numerical data collected through questionnaires (Sugiyono, 2012). These data emphasize objective measurement and statistical analysis using computational techniques. Primary data are used for the purpose of the study. These data are original in nature, firsthand collected specifically for the current objective of the study through questionnaires on information technology, internal control, organizational commitment, good corporate governance and organizational performance.

These data are subjected to correlation and regression analysis in SPSS which produces basic descriptive statistics. Both correlation and regression tests are part of classical assumption test, given that a statistical model always embodies a set of assumption concerning the population. Hypothesis testing is carried out in a multiple regression model.

\section{Result and Discussion}

In the primary data collection, the data are collected using questionnaires, where 50 respondents are exposed to the same questions and the same system of coding. These respondents include the branch heads and their subordinates in 3 study sites, i.e., Ambon, Masohi and Piru with at least 2 years' service. The number of returned questionnaires is 42 copies, comprising 40 with completed responses (thus 
eligibile for inclusion in the analysis) and 2 with incomplete responses. Respondents are classified according to sex, age, education and length of employment in the current service.

Table 1. Delivery, Completion and Return of Questionnaires

\begin{tabular}{ll}
\hline Delivered questionnaires & 50 \\
Returned questionnaires & 42 \\
Incomplete questionnaires & 2 \\
Completed questionnaires eligible for data processing and analysis & 40 \\
Response rate & $84 \%$ \\
Useable response rate & $80 \%$ \\
\hline
\end{tabular}

Questionnaires are checked when they first arrive from the field for the correct numbers of questionnaires and selection of eligible respondents. The present study uses 50 respondents, and, of these, 40 are eligible. The profile of the respondents is summarized in Table 2.

Table 2. The Profile of Respondents

\begin{tabular}{lll}
\hline Description & Total & Percentage (\%) \\
\hline Sex: & & \\
a. Male & 19 & $35 \%$ \\
b. Female & 21 & $39 \%$ \\
Age: & 9 & $17 \%$ \\
a. $17-26$ years & 11 & $20 \%$ \\
b. $27-36$ years & 15 & $28 \%$ \\
c. $37-46$ years & 5 & $9 \%$ \\
d. $>$ 46 & & \\
Education: & 15 & $28 \%$ \\
a. Senior High School & 2 & $4 \%$ \\
b. Diploma & 23 & $43 \%$ \\
c. Undergraduate & 0 & $0 \%$ \\
d. Graduate & & \\
Tenure: & 22 & $41 \%$ \\
a. $1-10$ years & 13 & $24 \%$ \\
b. $11-20$ years & 5 & $9 \%$ \\
c. $>$ 20 years & & \\
\hline
\end{tabular}

Tabel 2 reveals no significant difference between sexes, where the female respondents slightly exceed the male counterpart, accounting for $39 \%$ and $35 \%$, respectively. In terms of age, 9 respondents are aged between 17 and 26 (17\%), 11 respondents between 27 and 36 (20\%), 15 respondents between $37-46(28 \%)$, and 5 respondents older than $47(9 \%)$.

When it comes to educational attainment, 15 respondents (28\%) have graduated from senior high school, 2 respondents (4\%) from diploma education and 23 respondents (43\%) from undergraduate education. As for length of employment, 22 respondents (41\%) have served for 1-10 years, 13 respondents (24\%) for 11-20 years and 5 respondents (9\%) for more than 20 years.

Once the study of research methods provides the necessary guidelines in choosing methods and scientific tools to the subject of interest, the researcher first seeks to test the validity and reliability of the measurement instrument to obtain high data quality.

Questions on a questionnaire are valid when they measure what they are supposed to. A drafted questionnaire, therefore, should always be ready for establishing validity. The value of ral is compared with rtable for degree of freedom (df) $=n-k$, where $n$ is the sample, in order to determine the significance level of the statistic. With the sample (n) of 40 and $\mathrm{df}$ of 38 (40-2) at an alpha of 0,05 , the resulting $\mathrm{r}^{\text {table }}$ is 0,312 . The result of validity test in SPSS is presented in Table 3. 
Table 3. Result of Validity Test

\begin{tabular}{|c|c|c|c|}
\hline Variable & Item & Pearson Correlation & Description \\
\hline \multirow[t]{7}{*}{ Information Technology } & TI1 & 0,860 & Valid \\
\hline & TI2 & 0,783 & Valid \\
\hline & TI3 & 0,854 & Valid \\
\hline & TI4 & 0,809 & Valid \\
\hline & TI5 & 0,685 & Valid \\
\hline & TI6 & 0,704 & Valid \\
\hline & TI7 & 0,624 & Valid \\
\hline \multirow[t]{4}{*}{ Organizational Commitment } & K1 & 0,657 & Valid \\
\hline & K2 & 0,761 & Valid \\
\hline & K3 & 0,714 & Valid \\
\hline & K4 & 0,591 & Valid \\
\hline \multirow[t]{8}{*}{ Internal Control } & PI1 & 0,687 & Valid \\
\hline & PI2 & 0,732 & Valid \\
\hline & PI3 & 0,791 & Valid \\
\hline & PI4 & 0,598 & Valid \\
\hline & PI5 & 0,692 & Valid \\
\hline & PI6 & 0,704 & Valid \\
\hline & PI7 & 0,471 & Valid \\
\hline & PI8 & 0,488 & Valid \\
\hline \multirow[t]{16}{*}{ Principles of GCG } & T1 & 0,579 & Valid \\
\hline & $\mathrm{T} 2$ & 0,800 & Valid \\
\hline & T3 & 0,824 & Valid \\
\hline & $\mathrm{T} 4$ & 0,825 & Valid \\
\hline & A1 & 0,664 & Valid \\
\hline & $\mathrm{A} 2$ & 0,726 & Valid \\
\hline & A3 & 0,613 & Valid \\
\hline & R1 & 0,710 & Valid \\
\hline & R2 & 0,648 & Valid \\
\hline & R3 & 0,710 & Valid \\
\hline & I1 & 0,834 & Valid \\
\hline & I2 & 0,785 & Valid \\
\hline & I3 & 0,781 & Valid \\
\hline & F1 & 0,643 & Valid \\
\hline & F2 & 0,735 & Valid \\
\hline & F3 & 0,628 & Valid \\
\hline \multirow[t]{5}{*}{ Organizational Performance } & KP1 & 0,813 & Valid \\
\hline & KP2 & 0,867 & Valid \\
\hline & KP3 & 0.822 & Valid \\
\hline & KP4 & 0,807 & Valid \\
\hline & KP5 & 0,754 & Valid \\
\hline
\end{tabular}

$\mathrm{R}^{\text {cal }}$, as it appears in the table, for each variable is greater than rtable $(0,312)$. The correlation between each question item and the total score of the variable is significant (at 0,05$)$, thus allowing the researcher to make a valid prediction about the construct being assessed.

A test cannot be valid unless it is reliable. Cronbach's alpha determines the internal consistency or average correlation of items in the questionnaire to gauge its reliability, with a minimum acceptable value for Cronbach's alpha greater than 0,60 (Ghozali, 2005). Table 4 presents the result of the reliability test for each variable.

Table 4. Result of Reliability Test

\begin{tabular}{llll}
\hline No & Variable & Cronbach's Alpha & Description \\
\hline 1 & Information Technology & 0,874 & Reliable \\
2 & Organizational Commitment & 0,602 & Reliable \\
3 & Internal Control & 0,800 & Reliable
\end{tabular}




\section{No Variable}

$4 \quad$ Principles of GCG

5

Organizational Performance
Cronbach's Alpha

0,937

0,871
Description

Reliable

Reliable

Cronbach's alpha for each instrument is greater than 0,60 , thus indicating satisfactory internal consistency reliability to measure the same construct.

It is important that any statistical modelling conform to the assumptions of linear regression. Serious violations of these assumptions can result in biased and misleading estimates of relationships. The following are the four principal assumptions that justify the use of linear regression model for the purpose of inference of prediction:

Normality test aims to test whether both free variables and bound variable are normally distributed in a regression model. A linear regression model assumes that the sampling distribution is normal or, at least, near-normal. A histogram and normal probability plot are used to provide a graphical representation of the data normality.

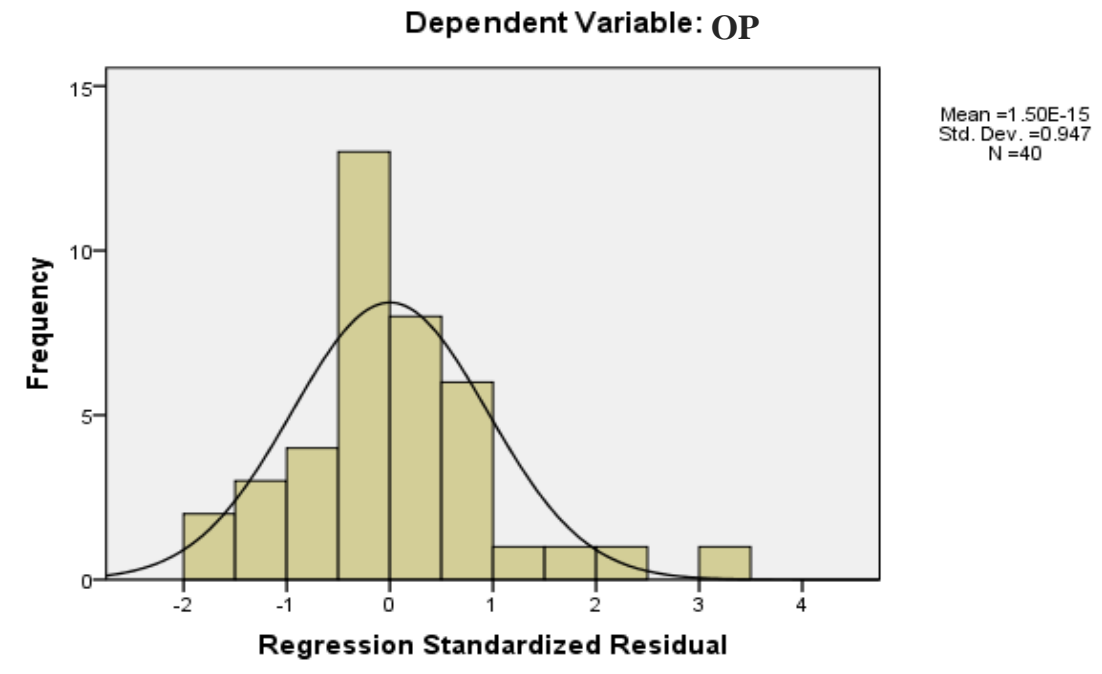

Figure 1. Histogram Graph

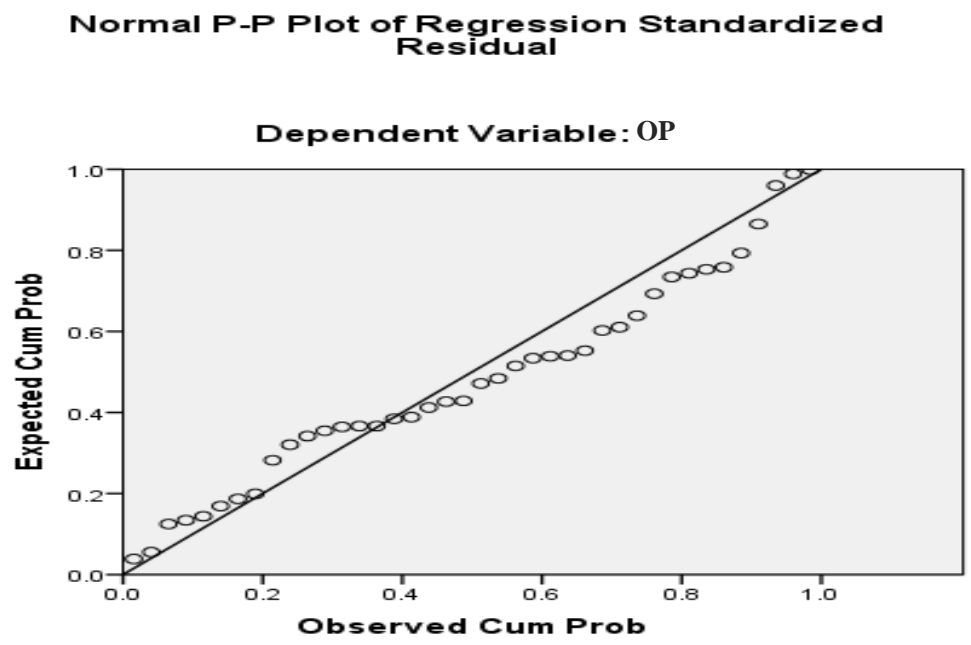

Figure 2. Normal Probability Plot

Figure 1 and 2 present the use of graphical methods to examine residuals. Histogram in Figure 1 shows a bell-shaped curve, which is a common pattern of normal distribution. Normal probability plot in Figure 2 shows that the points on the scatter plot align with the diagonal line, indicating that the residuals conform to a normal distribution.

The key goal of multicollinearity test is to isolate the relationship among the predictor variables because they should be independent. Tolerance and Variance Inflation Factor (VIF) are two closely related 
statistics to diagnose multicollinearity in a multiple regression. VIF is the reciprocal of the tolerance value. Tolerance value greater than 0,10 indicates low correlation among variables under ideal condition. However, it is acceptable if the VIF is less than 10.

Table 5. Result of Multicollinearity Test

\begin{tabular}{lll}
\hline & \multicolumn{2}{l}{ Collinearity Statistics } \\
\cline { 2 - 3 } Model & Tolerance & VIF \\
\hline $1 \quad$ (Constant) & & \\
IT & .450 & 2.221 \\
OC & .510 & 1.961 \\
IC & .642 & 1.556 \\
GCG & .429 & 2.329 \\
\hline
\end{tabular}

Description

IT : Information Technology

OC : Organizational Commitment

IC : Internal Control

GCG : Good Corporate Governance

The tolerances for all variables are greater than 0,10 , which corresponds to VIF values less than 10 , indicating no multicollinearity is at hand. In other words, the regression model assumes that the predictor variables are not highly correlated with each other, thus making them independent from each other.

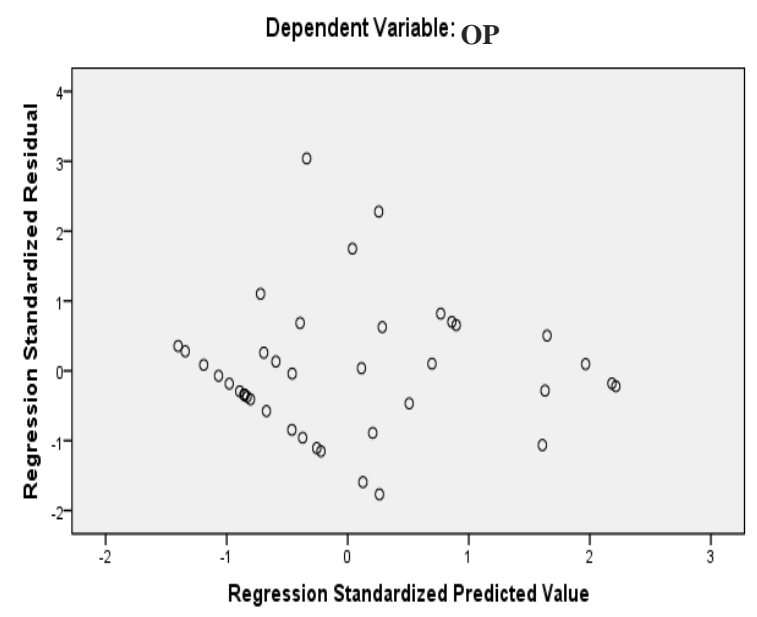

Figure 3. Scatter Plot

The points in the scatter plot are spread so randomly that no obvious pattern can be drawn as the points tend to cluster below zero on $\mathrm{Y}$ axis. No heteroscedasticity is, thus, present, and the independent variables should be of good use in inferential or predictive analysis.

Multiple regression analysis is used to test hypotheses to model a measure of effect within the data. Mutiple regression model involves with the following measures: Coefficient of determination is a measure that assesses the ability of independent variables to explain the proportion of variance in a dependent variable. The coefficient of determination is shown in the column of adjusted R-squared below:

Table 6. Coefficient of Determination $\left(R^{2}\right)$

Model Summaryb

\begin{tabular}{lllll}
\hline Model & $\mathrm{R}$ & R-Squared & Adjusted R- Squared & Std. Error of the Estimate \\
\hline 1 & $.803^{\mathrm{a}}$ & .645 & .604 & 1.237 \\
\hline
\end{tabular}

a. Predictors: (Constant), GCG, IC, OC, IT

b. Dependent Variable: OP 
$\mathrm{R}$ value of 0,803 or $80,3 \%$ indicates a strong correlation among the independent variablesinformation technology, organizational commitment, internal control and the principles of GCG - as it lies in the range of 0,80-0,99 (Riduwan and Engkos Achmad Kuncoro, 2007). The resulting adjusted Rsquared is 0,604 or $60,4 \%$, implying that $60,4 \%$ variance in organizational performance can be explained by the independent variables. The remaining 0,396 or $39,6 \%$ of the variation is presumably subject to random variability.

Table 7. Result of Simultaneous Test (F Test)

\begin{tabular}{ccccccc}
\hline & Model & Sum of Squares & Df & Mean Square & F & Sig. \\
\hline 1 & Regression & 97.386 & 4 & 24.347 & 15.901 & $.000^{\mathrm{a}}$ \\
& Residual & 53.589 & 35 & 1.531 & & \\
& Total & 150.975 & 39 & & & \\
\hline
\end{tabular}

a. Predictors: (Constant), GCG, IC, OC and IT

b. Dependent Variable: OP

The resulting Fcal is 15.901 at a significance level of 0.000 . In this circumstance, where the significance level stands below 0.05 , information technology, organizational commitment, internal control and the principles of GCG have significant simultaneous effects on organizational performance.

Table 8. Result of Individual Test (T Test)

\begin{tabular}{|c|c|c|c|c|c|c|c|}
\hline \multirow[b]{2}{*}{ Model } & & \multicolumn{2}{|c|}{ Unstandardized Coefficients } & \multicolumn{4}{|c|}{ Standardized Coefficients } \\
\hline & & B & Std. Error & Beta & t & & \\
\hline \multirow[t]{5}{*}{1} & (Constant) & .237 & 2.977 & & & .079 & .937 \\
\hline & TI & -.039 & .113 & & -.051 & -.341 & .735 \\
\hline & $\mathrm{K}$ & .187 & .206 & & .128 & .910 & .369 \\
\hline & PI & .097 & .092 & & .132 & 1.049 & .302 \\
\hline & GCG & .237 & .054 & & .670 & 4.357 & .000 \\
\hline
\end{tabular}

a. Dependent Variable: Organizational Performance

The regression equation from the table above is:

$Y=\alpha+b 1 X 1+b 2 X 2+b 3 X 3+b 4 X 4+e$

$\mathrm{Y}=0,237-0,039 \mathrm{X} 1+0,187 \mathrm{X} 2+0,097 \mathrm{X} 3+0,237 \mathrm{X} 4$

The SPSS output in Table 4.8 shows, among the independent variables in the regression model, that GCG has the only significant effect on organizational performance as its probability value ( $p$ value) is 0,000 (sig. < 0,05). Other independent variables are not statistically significant due to $p$ value $>0,05$.

The following section presents the result of hypothesis testing based on the test. The Effect of Information Technology on Organizational Performance The individual or partial test that measures information technology and organizational performance results in $t^{\text {cal }}$ of 0,341 at a significance level of $0,735>0,05$. For the fitting of multiple regression test, the coefficient value is $-0,039$. That is to say, information technology has a negative and non significant effect on organizational performance.

There are many technologies that significantly boost productivity and workstyles that go with them. It is important to note, however, that adopting technology involves more than having computers and an Internet connection in a workplace. To emphasize, it requires complex understanding of the types of hardware and software solutions to improve the way business works. These collaborative applications encourage high organizational performance level, most notably for organizations with geographicallydistributed setups like PT. Bank Maluku, where it can reduce the frustration of traveling for business purposes, which is expensive and time-consuming. Barriers to high-paced business mobility and, thus, poor organizational performance, remain if it resists or fails to keep up with this progress.

There is another indication that PT. Bank Maluku, supposing that it has facilitated digital workstyles in its systems and policies, has not focused on specifically arranging structured courses designed to meet job-related training goals to create growing awareness and promotion of accessible technologies in all aspects of its employment and build team capacity. Adaptation in training platform and 
environment is sufficient to introduce new skills at the scale that is necessary to help its employees keep abreast of the new demands and changing circumstances.

This finding corresponds with a previous study by Kurniawan R. (2008) that indicates a significant negative effect of the use of IT on organizational performance. Suprianto Edy (2004) shows similar finding in SKPD in Demak Regency, indicating positive yet insignificant effect of information technology on its organizational performance.

The Effect of Organizational Commitment on Organizational Performance With tcal $=0,910$ at a significance level of 0,369>0,05 and coefficient of 0,187, the effect of organizational commitment on organizational performance is positive but not significant.

Several positive effects result when the employees of PT. Bank Maluku commit to their work and the organization, in general. In its people-centric work culture, organizational commitment is not just about a sense of connection with the organization's goals but also willingness to pick up the slack of a missing employee, which means that they are prepared to dig in more work than they are individually responsible for. Strong organizational commitment, sometimes indicated by long tenure within the organization, remains even in the case of their different personal values from the organizational values.

However, as organizational commitment becomes more integral to the operations or missions of PT. Bank Maluku, this work ethic does not significantly impact the workplace, but has probably more to do with affecting how its employees work especially in a teamwork. This might go down to two indicators; 1 ) it sets goals that are achievable, but the bar is so low that it cannot achieve the mark it is aiming for; or 2) it sets unrealistic goals, and the bar is so high that it creates a culture of failure. Goal setting is critical to ensure its success, and the employees who make commitment held accountable to these goals are substantially more likely to accomplish them.

Rudi Susanto (2015) is consistent with this finding, claiming that employee commitment does not affect the government manajerial performance. Taufeni and Dian Kemala (2013) also find no significant effect of organizational commitment on the performance of public sectors. Fenty Astrina (2016) finds positive yet insignificant effect of organizational commitment in UM Palembang. Astrina elaborates on the inconsistent establishment of reward and punishment in this sense. She describes promising rewards for desirable achievement and punishment for undesirable side effects. Reward system and compensation package fail to secure employee commitment when they are viewed as inconsistent, unfair and unequitable. When they do not agree with the performance management system, they are likely to be unwilling to take an active part in the process where they do not see any value. However, Putu Dian Kusumasari, et al. (2017) find a contradictive finding that organizational commitment significantly affects the performance of LPD Ubud.

The concept of organizational commitment seems to almost fade away. Most employees want to keep their careers moving forward and earn more earnings. They hop from one to another organization for career development. Ironically, they seek for organizations that are willing to be more committed to them, i.e., organizations who trumpet their values and are more sensitive to their needs. Therefore, there should be a strong leadership involvement and commitment to invest in its employees as they remain committed to the organization and to stay focused on business goals and driving its future (Fenty Astrina, 2016).

The Effect of Internal Control $\left(X^{3}\right)$ on Organizational Performance $(Y)$ With tal $=1,049$ at a significance level of 0,302 >0,05 and coefficient of 0,132 , the effect of internal control on organizational performance is positive but not significant.

Contrary to this finding, Suryo Pratolo (2008) finds a direct relationship between internal control and organizational performance. Nur Azlina and Ira Amelia (2014) similarly reveal the performance of regional government recuperates as the internal control is properly managed.

The effectiveness of internal control is a critical component of the overall audit process in banking sector. The complexity of banking operations in the ever-changing globalized era, along with the increase in fraudulent activities, has garnered considerable attention on banking internal control system. This should be designed to provide a sufficient assurance to the responsible authorities when it comes to performing efficient operations, adhering to the applicable legislations and reporting reliable financial information. If these controls are strong enough, errors and irregularities can be always detected. However, it may provide a sufficient and, yet, not absolute, assurance that organizational objectives will be achieved if the entire framework of internal control does not represent each element of the internal banking environment that defines how it conducts its overall activities. It should include a wide array of components related to risk assessment, control environment, control activities, information and communication and monitoring that work as an integrated system in order to make a great impact on the strong and stable outlook of banking sector. 
The Effect of the Principles of Good Corporate Governance on Organizational Performance With tal $=$ 4,357 at a significance level of $0,000<0,05$ and coefficient of 0,670 , the effect of the principles of good corporate governance on organizational performance is positive and significant.

PT. Bank Maluku has represented current practical and effective principles of good corporate governance that has contributed to a standard of organizational performance. This finding is in line with A.A. Lina Triadi and I.D.G Dharma Suputra (2016), who contend that a well-governed organization implements the basic cores of good corporate governance principles that maintain the course for all aspects within the organization. PT. Bank Maluku can fulfill its obligations to shareholders, stakeholders, business partners, consumers and society, in general, and consider their rights based on fairness and transparency so that they are less prone to slip into conflict or tension when different interests collide. Transparency of both financial and non financial information about how it operates its business governs the shareholder and public trust, which is the most valuable asset for business. The principle of transparency is closely associated with accountability. In order that officials may be held accountable, the decisions and actions in the organization are open to public scrutiny, and the public has a right to access organizational information. It refers to the degree to which the organization has to explain or justify what it has achieved or failed to do. Within sufficient responsibilities, employees can fulfill their professional obligation and work ethics to maximize positive impacts and minimize negative impacts. These concepts are very central to the very idea of good corporate governance.

A vast array of previous work corroborates this finding. Triadi Lina A.A., and I.D.G. Dharma Suputra (2016) demonstrate a similar finding in the correlation between good corporate governance and manajerial performance. Fenty Astrina (2016) finds such significant relationship in UM Palembang. Putu Dian Kusumasari, et al. (2017) observe the good corporate governance that improves the performance of LPD in Ubud.

\section{Conclussion}

Berdasarkan This present study has provided empirical examination of information technology, organizational commitment, internal control and the principles of good corporate governance and highlighted the significance of measuring these constructs in promoting organizational performance and identifying effectiveness goals tailored to organizational needs. To this end, $\mathrm{f}$ test and $\mathrm{t}$ test are performed to set up the premises and determine the significance level. F test shows that these constructs have significant positive effects on organizational performance of PT. Bank Maluku. T test on which individual observations are based shows different statistical significance; insignificant negative effect of information technology, insignificant positive effect of organizational commitment and internal control, and significant positive effect of the principles of good corporate governance on organizational performance.

These findings have broad important implications for both assessing and constructing the notion of a well-governed organization, offering practical contributions to executives and managers at PT. Bank Maluku Tbk when it comes to decision making in organizational leadership and management practices through the application of information technology, organizational commitment, internal control and good governance control. In general, these findings provide a substantial context for the purpose of advancement within the field of public sector accounting. It is also a contribution to literature development to identify the likely directions for future research.

The researcher identifies a range of areas for attention with respect to the study findings:

1. A much larger set of samples and longer observations would help to widen the scope and perhaps reveal interesting comparable findings that can broaden and validate a set of defining characteristics.

2. Concerns with sampling in quantitative study also focus on determining how many of what types of cases or observations are needed to reliably represent the whole system and to minimize both falsely identifying or missing relationships between variables. It is also important to expand the set of indicators, including development of a better understanding of how to best implement information technology, organizational commitment, internal control and good corporate governance, with more emphasis on producing a flexible and adaptable workforce, for instance. 


\section{Reference}

Andriyanto, Nova. 2013. Pengaruh Pengendalian Intern dan Penerapan PrinsipPrinsip Good Corporate Governance Terhadap Kinerja Manajerial (Studi Empiris Pada PT BRI (Persero) Tbk Cabang Jember). Skripsi Akuntansi, Fakultas Ekonomi, Universitas Jember.

Aren Komuru. 2005. Analisis Faktor-Faktor Yang Mempengaruhi Kinerja Sistem Informasi Akuntansi. SNA VII. Solo.

Astuti, Feni. 2010. Analisis Pengaruh Pengendalian Intern, Budaya Organisasi, dan Penerapan Penerapan Prinsip Good Corporate Governance Terhadap Kinerja Perusahaan (Studi empiris pada PT Bank Mandiri (Persero) Tbk cabang Banyuwangi). Skripsi. Universitas Jember

Bank Indonesia. 2006. Peraturan Bank Indonesia No. 8/4/PBI/2006 tentang Pelaksanaan Good Corporate Governance Bagi Bank Umum, Jakarta.

Chaizi Nasucha, 2004, Reformasi Administrasi Publik, Grasiondo, Bandung

Efendi, 2009. Rasio Profitabilitas, Rasio Solvabilitas, dan Risiko Sistematis. Jurnal Ikatan Akuntansi Indonesia. Tidak Diterbitkan

Fauzi, Akhmad, Pengantar Teknologi Informasi. Yogyakarta: Graha Ilmu, 2008.

Fenty Astrina, 2016, Pengaruh Budaya Organisasi, Komitmen Organisasi Dan Penerapan Prinsip-Prinsip Good Corporate Governance (GCG) Terhadap Kinerja Perguruan Tinggi Dengan Pendekatan Balanced Scorecard (BSC), Jurnal Ilmiah Ekonomi Global Masa Kini Volume 7 No.01

Fierda Pangestika, 2016, Pengaruh Pengendalian Internal, Good Governance, Dan Komitmen Organisasi Terhadap Kinerja Pegawai Keuangan Kabupaten Temanggung, Jurnal Profita Edisi 8 Tahun 2016.

Ghozali, Imam. 2005. Aplikasi Analisis Multivariate dengan Program IBM SPSS 19. Semarang: Badan Penerbit Universitas Diponegoro.

Hall, Matthew. 2004. "The Effect of Comprehensive Performance Measurement Systems on Role Clarity, Psycological, Empowerment and Managerial Performance”. Accounting Organizations and Society, Vol.33, No.3: 141-163

Ikatan Akuntan Indoensia, 2001. Standar Profesional Akuntan Publik, Yogyakarta: Bagian Penerbitan STIE YKPN.

Irham Fahmi, 2003, Manajemen Kinerja, ALFABETA, Bandung.

Kadir, A \& Triwahyuni, T.C., 2003. Pengenalan teknologi informasi, Yogyakarta: Andi.

Kaihatu, Thomas S. 2006. Good Corporate Governance dan Penerapannya di Indonesia. Jurnal Manajemen dan Kewirausahaan

KEPMEN BUMN No. KEP-117/M-MBU/2002 tgl 31 Juli 2002 Tentang Peneraan Praktek Good Corporate Governance pada Badan Usaha Milik Negera (BUMN)

Kurniawan, R, 2008. “Analisis Pengaruh Teknologi Informasi Pada Kinerja Organisasi Study Empiris PT. Bank Rakyat Indonesia (PERSERO) Tbk Unit.

Luthans, Fred. 2006. Organizational Behavior 9th Edition. New York: McGraw-Hill.

Leo J. Susilo dan Karlen Simarmata. 2007. Good Corporate Governance pada Bank: Tanggung Jawab Direksi dan Komisaris dalam Melaksanakannya. Jakarta: PT Hikayat Dunia.

Mardiasmo. 2004. Akuntansi Sektor Publik. Yogyakarta: Andi 
Nugroho Widjajanto. 2001. Sistem Informasi Akuntansi. Jakarta : PT Glora Aksara Prima.

Nur Azlina, Ira Amelia, 2014, Pengaruh Good Governance Dan Pengendalian Intern Terhadap Kinerja Pemerintah Kabupaten Pelalawan, Jurnal Akuntansi Universitas Jember - Vol. 12 No. 2

Oktari, Ranti. 2011. Pengaruh Pemanfaatan Teknologi Informasi terhadap Kinerja Instansi Pemerintah Daerah. Jurnal Akuntansi Fakultas Ekonomi Universitas Riau :Pekanbaru.

Peraturan Pemerintah Republik Indonesia Nomor 60 Tahun 2008 tentang sistem pengendalian pemerintah

Prakarsa, Wahyudi. 2009. Sistem Pengukuran Kinerja-Pendekatan Kontemporer, Diskusi Nasional, Jakarta

Pratolo Suryo. 2008. Pengaruh Audit Manajemen, Komitmen Organisasional Manajer, Pengendalian Intern terhadap Penerapan Prinsip-Prinsip Good Corporate Governance dan Kinerja Badan Usaha Milik Negara di Indonesia. Jurnal Akuntansi dan Investasi. Vol. 9 No. 1, Januari.

Priambodo Dwi Irfan, Yuli Tri Cahyono. 2015. Pengaruh Penerapan Prinsip-Prinsip Good Corporate Governance, Pengendalian Intern, Dan Teknologi Informasi Terhadap Kinerja Manajer Unit. Naskah Publikasi

Putri, Gustika Yolanda. 2012. Pengaruh Komitmen Organisasi Dan Sistem Pengendalian Intren Pemerintah (Spip) Terhadap Kinerja Manajerial Skpd Di Kota Padang. Journal Article.

Putu Dian Kusumasari, Ni Kadek Sinarwati, Gede Adi Yuniarta (2017), Pengaruh Penerapan PrinsipPrinsip Good Corporate Governance, Komitmen Organisasi, Gaya Kepemimpinan Dan Pengawasan Internal Terhadap Kinerja Lembaga Perkreditan Desa, e-Journal S1 Ak Universitas Pendidikan Ganesha, Volume 7 No 1 Tahun 2017.

Rahmawati, dan Zaki Baridwan. 2006. "Pengaruh Asimetri Informasi, Regulasi, Perbankan dan Ukuran Perusahaan Pada Manajemen Laba Dengan Model Akrual Khusus Perbankan (Studi Empiris Pada Industri Perbankan di Indonesia yang Terdaftar di BEJ)". Jurnal Akuntansi dan Bisnis Indonesia, Vol 6 No. 2, Agustus.

Ristifani. 2009. "Analisis Implementasi Prinsip-Prinsip GCG dan Hubungannya Terhadap Kinerja PT. Bank Rakyat Indonesia Tbk". Skripsi tidak dipublikasikan. Universitas Gunadarma.

Robbins, Stephen P. 2006. Perilaku Organisasi, Edisi Indonesia . PT. Indeks, Kelompok Gramedia.

Rudi Susanto, 2015. "Pengaruh Good Governance, Pegendalian Internal, Komitmen Organisasi, dan Pengelolaan Keuangan Daerah terhadap Kinerja Manajerial Pemerintah Daerah". Skripsi. Program Studi Akuntansi Universitas Pembangunan Nasional.

Rustiana, Siti Hamidah. 2004. Pengamh Strategi dan Budaya Perusahaan Terhadap Kinerja Manajer PT Kinia Farma Apotek: Good Corporate Governance Sebagai Variabel Intervening. Tests. Universitas Sumatera Utara.

Sopiah. 2008. Perilaku Organisasi. Yogyakarta: Andi.

Sugiyono. 2012. Statistika Untuk Penelitian. Bandung: Alfabeta.

Suprianto Edy, 2014, Pengaruh Penerapan Tata Kelola Pemerintahan Yang Baik Dan Teknologi Informasi Terhadap Kinerja Satuan Kerja Perangkat Daerah (Skpd) Guna Mendukung Implementasi Otonomi Daerah, Jurnal EKOBIS Vol.15, No.1.

Suryo Pratolo. 2006. Pengaruh Audit Manajemen, Komitmen Manajer pada Organisasional, Akuntabilitas publik terhadap Penerapan Prinsip-Prinsip good Corporate Governance dan Kinerja Perusahaan. Desertasi Doktor. Universitas Padjadjaran. Bandung. 
Taufeni, Dian Kemala, 2013, Pengaruh Pemahaman Prinsip-Prinsip Good Governance, Pengendalian Intern dan Komitmen Organisasi terhadap Kinerja Sektor Publik, Pekbis Jurnal, Vol.5, No.1, Maret 2013.

Triadi Lina A.A, I.D.G. Dharma Suputra. 2016. Pengaruh Pengendalian Intern dan Penerapan PrinsipPrinsip Good Corporate Governance Terhadap Kinerja Manajerial. E-Jurnal Akuntansi, Universitas Udayana. Vol 16. No. 2.

Tugiman, Hiro. 2000. Pengaruh Peran Auditor Intern Serta Faktor-Faktor Terhadap Peningkatan Pengendalian Intern dan Kinerja Perusahaan. Desertasi Doktor. Universitas Padjadjaran. Bandung. 